\title{
SIFAT KIMIA DAN MIKROBIOLOGI BAKASANG IKAN OCI (Rastrelliger sp) DENGAN LAMA FERMENTASI YANG BERBEDA
}

\author{
[Chemical and Microbiology Properties of Bakasang Ikan Oci (Rastrelliger sp) with Variation \\ Fermentation Time]
}

\author{
Anto*, Deyvie Xyzquolyna, Viene Valentine H.Ali \\ Program Studi Teknologi Hasil Pertanian Universitas Ichsan Gorontalo \\ *email: antostp63@gmail.com
}

Diterima 8 April 2019 / Disetujui 29 April 2019

\begin{abstract}
This study aimed to determine the effect of oci fermentation time on total microbes, total lactic acid bacteria, water content, protein content, and $\mathrm{pH}$ value. The oci fish used are fresh oci fish from the fish market in Gorontalo, then fermented for 0, 3, 10 and 15 days. The research method used the experimental method through a complete randomized design pattern using variance analysis followed by the Duncan test. For 15 days fermented, the pH value, water content and microbial total decreased, but the protein content and the number of lactic acid bacteria increased. The bakasang of oci at the end of fermentation has a total lactic acid bacteria of $2.51 \times 107$ CFU/g, the water content of $65.56 \%$, the protein content of $5.98 \%$, and $\mathrm{pH}$ value of 6.0 .
\end{abstract}

Keywords: oci fish, fermentation, bakasang, lactic acid bacteria

\section{ABSTRAK}

Tujuan penelitian ini adalah untuk menganalisa sifat kimia dan mikrobiologi bakasang ikan oci dengan lama fermentasi yang berbeda. Ikan oci yang digunakan adalah ikan oci segar dari pasar ikan di Gorontalo, lalu difermentasi selama 3, 10 dan 15 hari. Parameter pengamatannya meliputi sifat kimia yang terdiri dari kadar air, kadar protein, nilai pH. Sedangkan sifat mikrobiologi yang diamati yaitu total mikroba dan total bakteri asam laktat. Metode penelitian ini menggunakan rancangan acak lengkap dan analisis sidik ragam dilanjutkan dengan uji Duncan. Selama 15 hari difermentasi, nilai pH, kadar air dan total mikroba menurun, namun kadar protein dan jumlah bakteri asam laktat mengalami peningkatan. Bakasang ikan oci pada akhir fermentasi mempunyai total bakteri asam laktat 2,51x10 cfu/g, kadar air 65,56\%, kadar protein 5,98\%, dan nilai $\mathrm{pH} 6,0$.

Kata kunci; ikan oci, fermentasi, bakasang, bakteri asam laktat

\section{PENDAHULUAN}

Kekayaan alam laut Indonesia ditunjang oleh luas perairannya yang mencapai sekitar $70 \%$. Subsektor perikanan termasuk salah satu program keunggulan karena terdapat potensi ikan yang melimpah di Provinsi Gorontalo. Salah satu jenis ikan laut yang ada dan sangat digemari oleh masyarakat adalah ikan oci. Ikan Oci (Rastrelliger sp.) merupakan salah satu jenis ikan pelagis yang memiliki nilai ekonomis dan potensial setelah ikan layang karena volume produksinya mencapai 291.863 ton (Pusat Data Statistik Republik Indonesia, 2013). Selama ini ikan oci di Provinsi Gorontalo hanya dikonsumsi dengan cara digoreng atau dibakar. Keberadaannya yang melimpah dan sifat produk perikanan yang mudah rusak apabila tidak ditangani dengan baik, maka diperlukan proses pengolahan untuk meningkatakan nilai fungsional dari ikan oci.
Teknik pengolahan yang dapat menjadi alternatif adalah fermentasi dengan menggunakan garam. Penggunaan garam berkonsentrasi tinggi diharapkan dapat menekan pertumbuhan mikroba pembusuk dan hanya mikroba yang diharapkan yang hidup.

Produk fermentasi ikan yang mempunyai rasa yang asam biasa disebut bakasang. Untuk membuat bakasang, ikan sebagai bahan baku utama difermentasi selama 5-20 hari setelah ditambahkan garam dan nasi. Garam memiliki fungsi untuk mengikat air dan memberi rasa yang sedap, selain itu juga pertumbuhan mikroorganisme yang tidak dikehendaki dapat dihambat dengan adanya garam. Pada umumnya bakteri pembusuk relatif lebih sensitif terhadap garam. Garam dapat berfungsi sebagai bahan pengawet karena dapat menaikkan tekanan osmosis yang menyebabkan terjadinya plasmolisis pada sel mikroba (Buckle et.al., 1978) Penambahan nasi akan membuat 
lingkungan yang baik bagi pertumbuhan bakteri asam laktat. Selama fermentasi, karbohidrat akan diuraikan menjadi senyawa-senyawa yang sederhana seperti, asam laktat, asam asetat, asam propionat dan etil alkohol. Senyawasenyawa ini yang menyebabkan rasa asam pada produk dan dapat berfungsi sebagai pengawet (Rahayu et,al., 1992). Penelitian mengenai bakasang di Gorontalo telah dilakukan oleh Yanti dan Dali (2013), akan tetapi menggunakan ikan nike dan ikan cakalang.

Widiyastuti dan Sofarianawati (1999) dalam laporannya yang diacu oleh Yanti dan Dali (2013) menyatakan bahwa gula atau karbohidrat dapat diubah menjadi asam laktat oleh bakteri asam laktat melalui proses fermentasi. Pada proses fermentasi, bakteri asam laktat mempunyai peran yang sangat penting dalam perubahan aroma dan tekstur yang dapat meningkatkan keawetan produk akhirnya (Hugas, 1998). Keberhasilan pembuatan produk bakasang ditentukan dari peran dan jenis bakteri asam laktat yang terdapat dalam produk. Oleh karena itu, perlu dibuat kondisi yang ideal bagi pertumbuhan bakteri tersebut selama proses fermentasi berlangsung. Faktor-faktor lingkungan yang mempengaruhi pertumbuhan bakteri asam laktat antara lain adalah suhu, nilai pH, kadar garam dan karbohidrat. Desniar et.al (2015) melaporkan bahwa pada bekasem ikan mas, lama fermentasi 6 hari menunjukkan jumlah total bakteri asam laktat yang meningkat. Namun mengalami penurunan setelah hari ke 6 sampai hari ke 10 fermentasi. Sementara itu, menurut laporan Yanti dan Dali (2013), bakasang ikan nike yang berumur 3 hari dan diproduksi oleh masyarakat Manado menunjukkan total bakteri asam laktat 9,2 $\times 10^{4}$ $\mathrm{cfu} / \mathrm{g}$. Berdasarkan hal tersebut penelitian ini bertujuan untuk menganalisa sifat kimia dan mikrobiologi ikan oci (Rastrelliger $s p$ ) dengan lama fermentasi yang berbeda.

\section{BAHAN DAN METODE}

\section{Bahan}

Bahan yang digunakan dalam penelitian ini adalah ikan oci segar yang diperoleh dari pasar ikan Gorontalo, garam, gula, aquades, $\mathrm{NaCl}$ fisiologis $(0,85 \%)$, dan indikator phenolphthalein, media PCA (Plate Count Agar) dan MRSA (De Man Rogosa Sharpe Agar).

Alat

Alat-alat yang digunakan dalam penelitian ini adalah wadah fermentasi (toples), pipet, erlenmeyer, tabung reaksi, tabung Durham, timbangan analitik, mortar, pengaduk, labu ukur, gelas piala, biuret, pH-meter, gelas ukur, cawan petri, inkubator, oven, gelas objek, sudip, jarum ose, mikroskop cahaya, foto digital mikroskopik, water bath, pembakar bunsen, lemari es, autoklaf, vortex, pipet dengan kapasitas $1 \mathrm{ml}$, sendok steril, tabung dan botol dengan kapasitas $500 \mathrm{ml}$, plastik steril, stomacher, spiritus dan koloni counter.

\section{Prosedur Penelitian \\ Pembuatan Bakasang}

Ikan oci yang akan dibuat bakasang harus mempunyai ukuran berat yang sama dan seragam. Lalu dibuang kepala, ekor dan isi perut. Setelah itu dicuci sampai bersih. Ikan oci yang sudah bersih ditimbang masing- masing sebanyak 600 gram dipindahkan ke dalam wadah, ditambahkan garam sebanyak $25 \%$ dan diaduk hingga merata. Kemudian dimasukkan ke dalam toples, ditutup rapat dan difermentasi selama 3 hari pada suhu kamar. Setelah 3 hari ditambahkan nasi sebanyak $62,8 \%$ dan garam sebanyak 3,4\%. Lalu dilanjutkan fermentasinya selama 10 hari dan fermentasi selama 15 hari.

\section{Uji Kadar Air dan Kadar Protein}

Pengujian kadar air dan kadar protein dilakukan berdasarkan metode AOAC (1995).

\section{Uji Total Bakteri Asam Laktat (BAL)}

Uji total BAL dilakukan pada lama fermentasi $0,3,10$, dan 15 hari. Pengujian total BAL dilakukan berdasarkan metode hitungan cawan menurut Fardiaz (1989) dengan menggunakan media MRSA. Jumlah total BAL dinyatakan dalam cfu/g dan dihitung (skala 30300 koloni) berdasarkan rumus:

Total BAL $=$ jumlah koloni terhitung $\times \frac{1}{\mathrm{Fp}}$

Keterangan: $\mathrm{Fp}=$ faktor pengenceran 


\section{Uji Total Mikroba}

Total mikroba diuji dengan berdasarkan metode hitungan cawan dari Fardiaz (1989) pada lama fermentasi 0 hari, 3 hari, 10 hari dan 15 hari. Diambil sampel sebanyak $1 \mathrm{~g}$, dilakukan pengenceran dengan larutan garam fisiologis $(\mathrm{NaCl}$ 0,85\%) steril sebanyak $9 \mathrm{ml}$ dan ini dianggap sebagai pengenceran $10^{-1}$. Selanjutnya dilakukan lagi pengenceran dengan melarutkan $1 \mathrm{ml}$ larutan hasil pengenceran $10^{-1}$ dalam $9 \mathrm{ml}$ larutan garam fisiologis dan dihitung sebagai pengenceran $10^{-2}$. Demikian seterusnya sampai dengan pengenceran $10^{-7}$. Sebanyak $1 \mathrm{ml}$ sampel dari masing- masing pengenceran dipipet dan dimasukkan ke dalam masingmasing cawan petri steril, kemudian dituang PCA steril sebanyak $\pm 15 \mathrm{ml}$ (dilakukan secara duplo untuk tiap pengenceran) dan digoyangkan secara merata atau seperti angka 8 diatas meja. Setelah media agar menjadi padat, cawan dibungkus dengan kertas lalu diinkubasi posisi terbalik pada suhu $36-37^{\circ} \mathrm{C}$ selama 48 jam. Jumlah total mikroba dinyatakan dalam cfu/g.

\section{HASIL DAN PEMBAHASAN}

\section{Kadar Air Bakasang}

Kemampuan mikroba untuk tumbuh dan berkembang dipengaruhi oleh kadar air dalam suatu bahan (Winarno et al., 1993). Kadar air pada penelitian ini mengalami penurunan selama fermentasi namun nilainya berfluktuatif. Hasil analisis kadar air selama fermentasi ikan oci disajikan pada Gambar 1.

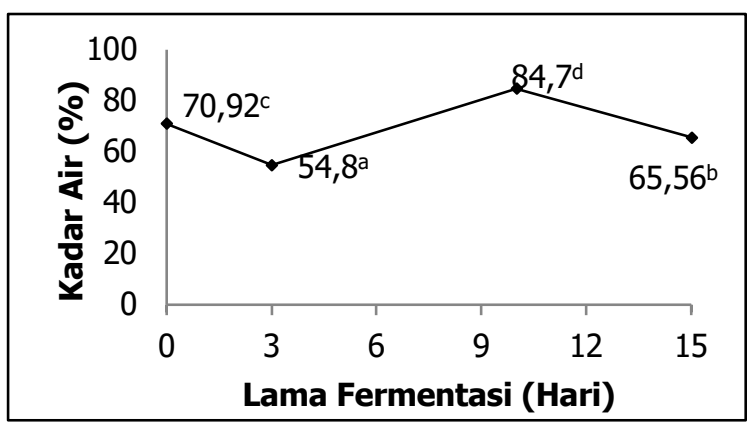

Gambar 1. Nilai rata-rata Kadar Air berdasarkan Lama Fermentasi (hari)

Secara statistik lama fermentasi memberikan memberikan perbedaan yang nyata terhadap kadar air bakasang ikan oci. Dari Gambar 1 menunjukkan kadar air awal bakasang ikan oci mengalami penurunan pada
ISSN: 2443-1095

lama fermentasi 3 hari. Penurunan ini terjadi akibat adanya penambahan garam sebanyak $25 \%$. Hal ini disebabkan karena air dalam bahan diserap oleh garam yang ditambahkan (Thariq, et al., 2014). Kemudian setelah difermentasi selama 10 hari kadar air bakasang mengalami kenaikan. Hal ini dimungkinkan karena jumlah garam yang ditambahkan pada hari ke- 3 tidak cukup banyak untuk mengikat air yang terlepas karena proses fermentasi.

\section{Kadar Protein}

Kadar protein pada penelitian ini cenderung mengalami peningkatan. Hasil analisis kadar protein ikan oci selama proses fermentasi disajikan pada Gambar 2.

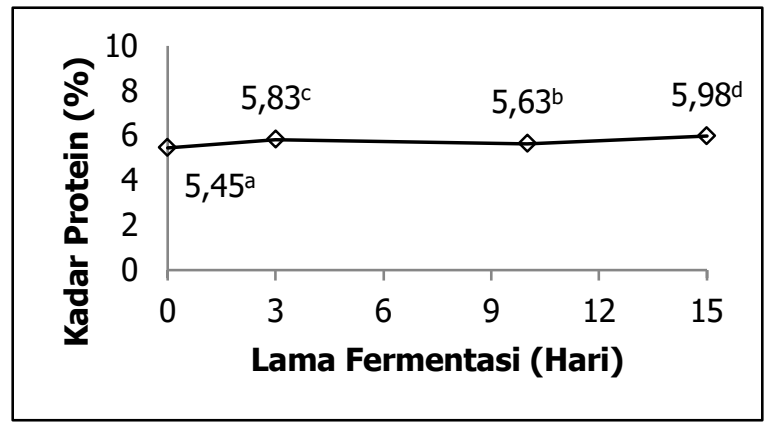

Gambar 2. Kadar Protein berdasarkan Lama Fermentasi

Hasil analisis protein pada penelitian ini menunjukkan nilai yang berfluktuasi. Pada fermentasi hari ke-3 kadar protein mengalami peningkatan, selanjutnya menurun pada fermentasi hari ke 10 dan meningkat lagi pada akhir fermentasi (hari ke 15). Berdasarkan hasil uji Duncan lama fermentasi memberikan perbedaan yang nyata terhadap kadar protein bakasang ikan oci. Menurut Bahalwan (2011) meningkatnya kadar protein dapat disebabkan karena menurunnya kadar air pada bakasang.

\section{Nilai pH}

Nilai $\mathrm{pH}$ adalah salah satu faktor fisikokimia yang sangat mempengaruhi keawetan bahan makanan. Mikroba dapat hidup dan berkembang biak di dalam lingkungan dengan suatu kondisi pH tertentu (Rahayu et.al., 1992). Hasil analisis nilai pH Ikan Oci selama proses fermentasi disajikan pada Tabel 1. 
Tabel 1. Nilai rata-rata $\mathrm{pH}$ terhadap Lama Fermentasi

\begin{tabular}{cc}
\hline $\begin{array}{c}\text { Lama Fermentasi } \\
\text { (Hari) }\end{array}$ & Nilai pH \\
\hline 0 & $6,5^{\mathrm{c}}$ \\
3 & $6,4 \mathrm{bc}$ \\
10 & $6,3^{\mathrm{b}}$ \\
15 & $6,0^{\mathrm{a}}$ \\
\hline
\end{tabular}

Hasil pengukuran nilai pH bakasang hingga akhir fermentasi menunjukkan bahwa nilai $\mathrm{pH}$ berada pada kondisi asam. Lama fermentasi selama 15 hari secara statistika memberikan perbedaan yang nyata terhadap penurunan $\mathrm{pH}$ dibandingkan pada lama fermentasi 3 dan 10 hari. Penurunan $\mathrm{pH}$ bakasang dalam penelitian ini disebabkan karena karbohidrat dalam penelitian ini terhidrolisis menjadi glukosa, dan oleh bakteri menggunakan glukosa sebagai energi untuk menghasilkan asam laktat. Hal ini sejalan dengan hasil penelitian Desniar et.al (2012) pada produk fermentasi ikan mas yaitu nilai $\mathrm{pH}$ mengalami penurunan seiring dengan jumlah BAL yang mengalami peningkatan. Nilai $\mathrm{pH}$ produk bekasem ikan mas juga mengalami penurunan dari 6,59 menjadi 5,20 selama fermentasi 10 hari (Desniar et.al., 2012). Menurut Simanjorang et.al (2012), pH yang rendah mempunyai kemampuan untuk membebaskan air yang terikat dengan senyawa kompleks dan mempunyai gugus hidrofilik menjadi air bebas, misalnya ikatan protein.

\section{Total Mikroba Bakasang Ikan Oci}

Total koloni bakteri mengalami peningkatan pada fermentasi hari ke 3 . Hal ini dapat disebabkan karena masih tersedianya nutrien yang cukup untuk proses pertumbuhan dan pembelahan sel bakteri. Lalu data menunjukkan adanya penurunan total mikroba pada hari ke 10 sampai hari ke 15 . Total mikroba pada bakasang ikan oci dapat dilihat pada Tabel 2.

Tabel 2. Total Mikroba Bakasang Ikan Oci

\begin{tabular}{c|c}
\hline $\begin{array}{c}\text { Lama Fermentasi } \\
\text { (hari) }\end{array}$ & $\begin{array}{c}\text { Total Mikroba } \\
\text { (x107 CFU/g) }\end{array}$ \\
\hline 0 & $0,406^{\mathrm{a}}$ \\
3 & $3,28^{\mathrm{b}}$ \\
10 & $2,94^{\mathrm{b}}$ \\
15 & $2,60^{\mathrm{a}}$ \\
\hline
\end{tabular}

Berdasarkan analisis statistik, total mikroba pada bakasang dengan lama fermentasi 0 hari memberikan perbedaan yang nyata dibandingkan total mikroba pada lama fermentasi 3, 10 dan 15 hari. Hal ini menurut Reiny (2012) dapat terjadi karena berkurangnya nutrien dan terbentuknya senyawa hasil metabolisme yang cenderung bersifat racun bagi bakteri. Suprihatin (2010), menambahkan bahwa semakin lama fermentasi, peningkatan total mikroba tidak signifikan seperti pada awal fermentasi, mikroba yang telah lama tumbuh akan mengalami kematian. Kematian mikroba ini dikarenakan nutrien dalam medium sudah habis dan energi cadangan didalam sel habis.

\section{Total Bakteri Asam Laktat (BAL) Bakasang Ikan Oci}

Total bakteri asam laktat bakasang ikan oci pada Gambar 1 penelitian ini mengalami peningkatan seiring dengan meningkatnya lama waktu fermentasi. Total BAL bakasang yang didapat dari lama fermentasi 0 hari secara statistik tidak berbeda nyata dengan bakasang yang didapat dari lama fermentasi 3 hari, namun berbeda nyata dengan bakasang yang didapat dari lama fermentasi 10 dan 15 hari. Peningkatan total bakteri yang terjadi pada fermentasi dapat disebabkan oleh keberadaan garam yang dapat merangsang pertumbuhan bakteri asam laktat. Kondisi asam pada lingkungan menyebabkan hanya bakteri asam laktat dan halofilik yang dapat tumbuh (Anwar, et.al., 2014). Total mikroba pada bakasang ikan oci dapat dilihat pada Tabel 3.

Tabel 3. Total BAL Bakasang Ikan Oci

\begin{tabular}{c|c}
\hline $\begin{array}{c}\text { Lama Fermentasi } \\
\text { (hari) }\end{array}$ & $\begin{array}{c}\text { Total BAL } \\
\left(\mathbf{x 1 0 ^ { 7 }} \text { CFU/g) }\right.\end{array}$ \\
\hline 0 & $0,365^{\mathrm{a}}$ \\
3 & $0,381^{\mathrm{a}}$ \\
10 & $2,13^{\mathrm{b}}$ \\
15 & $2,51^{\mathrm{b}}$ \\
\hline
\end{tabular}

Penelitian Purwaningsih et.al (2011) menyatakan bahwa selama fermentasi jeroan ikang cakalang selama 8 hari pemeraman terjadi peningkatan total mikroba dari 4,62 log cfu/g menjadi 5,15 log cfu/g. Lawalata et.al (2010) menemukan bahwa 98 isolat bakteri asam laktat yang terdapat pada bakasang (fermentasi jeroan 
Versi Online:

http://www.profood.unram.ac.id/index.php/profood e-ISSN: 2443-3446

ikan cakalang) memiliki daya hambat terhadap bakteri patogen dan pembusuk. Candra et.al (2007) menemukan jenis bakteri asam laktat pada bekasem ikan bandeng yaitu Lactobacillus, Streptococcus, Aerococcus dan Pediococcus.

\section{KESIMPULAN}

Fermentasi ikan oci selama 15 hari memberikan pengaruh yang nyata terhadap total bakteri asam laktat, kadar air, kadar protein dan $\mathrm{pH}$.

\section{UCAPAN TERIMA KASIH}

Terima kasih kepada Kementerian Ristek Dikti Republik Indonesia yang membiayai penelitian ini dalam hibah PEKERTI.

\section{DAFTAR PUSTAKA}

Anwar, L.O., L. Hardjito. Desniar. 2014. Fermentasi Tambelo dan Karakteristik produknya. Jurnal Pengolahan Hasil Perikanan Indonesia 17(3):254-262.

AOAC. 1995. Official Methods of Analysis. Virginia: The Association of Official Analytical and Chemist. 16 th ed. Arlington. AOAC Inc.

Buckle KA, Edwards RA, Fleet GH, Wootton M. 1978. Ilmu Pangan. UI Press. Jakarta.

Candra, J.I., Zahiruddin, W., Desniar. 2007. Isolasi dan Karakterisasi Bakteri Asam laktat dan Produk Bekasem Ikan Bandeng (Chanos chanos). Buletin Teknologi Hasil Perikanan 10(2):14-24.

Desniar., I. Setyaningsih., R.S Sumardi. 2012. Perubahan parameter kimia dan mikrobiologi serta Isolasi Bakteri Penghasil Asam Laktat selama Fermentasi
Pro Food (Jurnal IImu dan Teknologi Pangan)

Vol 5 No. 1 Mei 2019

ISSN: 2443-1095

Bekasem Ikan Mas (Cyprinus caprio). JPHPI 15(3):232-239.

Desniar, I. Rusmana, A. Suwanto, and N.R. Mubarik. 2013. Characterization of Lactic Acid Bacteria Isolated From an Indonesian Fermented Fish (Bekasam) and Their Antimicrobial Activity Against Pathogenic Bacteria. Department of Aquatic Product Technology.Faculty of Fisheries and Marine Sciences. Bogor. Emir. J. Food Agriculture 25 (6): 489-494.

Fardiaz S. 1989. Analisis Mikrobiologi Pangan Petunjuk Laboratorium. Institut Pertanian Bogor. Bogor.

Mueda, R.T. 2015. Physico-chemical and color characteristics of Salt Fermented Fish Sauce from anchovy Stolephorus commersonii. AACL Bioflux 8(4):565-572.

Purwaningsih, S., Garwan, R., Santoso. 2011. Karakteristik Organoleptik Bakasang Jeroan Cakalang (Katsuwonus pelamis, Lin) sebagai Pangan Tradisional Maluku Utara. Journal of Nutrition and Food 6(11):13-17.

Rahayu, W.P., Ma'oen, S., Suliantari., Fardiaz, S. 1992. Teknologi Fermentasi Produk Perikanan. Pusat Antar Universitas Pangan dan Gizi. Institut Pertanian Bogor

Suprihatin. 2010. Teknologi Fermentasi. Penerbit UNESA University Press.

Thariq, A.S., Swastawati, F., Surti, S. 2014. Pengaruh perbedaan konsentrasi garam pada Peda Ikan Kembung (Rastrelliger neglectus) terhadap Kandungan asam glutamate pemberi rasa gurih (Umami). Jurnal Pengolahan dan Bioteknologi Hasil Perikanan 3(3): 104-111.

Yanti, DIW. dan Dali, F.A. 2013. Karakteristik Bakteri Asam Laktat yang diisolasi selama fermentasi bakasang. JPHPI 16(2):133141. 